【原著】

\title{
リボフラビン溶液中への UVA 照射によるスーパーオキシド生 成に対する各種精油（エッセンシャルオイル）の効果 Effects of Some Essential Oils on Superoxide Radical Formation in the Reaction Mixture of Riboflavin under UVA Irradiation
}

【要 旨】

目的：リボフラビン溶液への UVA $(365 \mathrm{~nm})$ 照射によるスーパーオキシド生成に対する ティートリーオイル等各種精油の影響につい て検討した.

方法：15 $\mu \mathrm{M}$ リボフラビン, $0.10 \mathrm{M}$ DMPO (5,5-dimethyl-I-pyrroline- $N$-oxide), $23 \mathrm{mM}$ リ ン酸緩衝液 $(\mathrm{pH} 7.4), 6.3 \%(\mathrm{v} / \mathrm{v}) \mathrm{DMSO}$ (dimethyl sulfoxide) を含む反応溶液（標準反 応溶液)に UVA $(365 \mathrm{~nm})$ を照射し, ESR (electron spin resonance: 電子スピン共鳴)を 測定した.

結果：標準反応溶液に各種精油を種々の濃度 で添加すると, ESR ピーク高は濃度依存的に 減少した.

結論：各種精油の抗酸化能は以下の順に大き くなった：ラベンダースーパーオイル<グ レープフルーツオイル<ペパーミントオイル <ティートリーオイル<ウインターグリーン オイル.

【キーワード】

リボフラビン, スーパーオキシド，ティート

リーオイル，電子スピン共鳴

\author{
森 広子 ${ }^{1,2, *}$, 岩橋秀夫 ${ }^{1}$ \\ Hiroko MORI ${ }^{1,2, *}$, Hideo IWAHASHI ${ }^{1}$ \\ 1 和歌山県立医科大学大学院医学研究科生体分子解析学 \\ 2 森ノ宮医療学園専門学校
}

はじめに

アロマセラピーで用いられる精油中には，有機化合物 が数十一数百種類含まれて和り, 特有の香りと様々な薬 理作用がある1,2)。このようなことから，アロマセラピー は補完代替医療の一つとして研究が進められている ${ }^{3-5)}$.

紫外線により, 一重項酸素 $\left(\mathrm{I}_{2}\right)$, スーパーオキシド $\left(\mathrm{O}_{2}^{-}{ }^{-}\right)$, ヒドロキシラジカル $(\cdot \mathrm{OH})$, 過酸化水素 $\left(\mathrm{H}_{2} \mathrm{O}_{2}\right)$ な ぞ各種活性酸素が生成される。精油の一重項酸素への影 響については詳細な研究が進められて扮り, 各種精油の 一重項酸素消去能あるいは一重項酸素生成促進作用が明 らかとなっている6-8). しかしながら, UVA (ultraviolet-A) 照射下でのスーパーオキシド生成に対する, 精油の抗酸 化能についての研究はほとんど行われていない.

リボフラビンは光増感剤として知られており,リボフ ラビンを含む反応溶液に UVA を照射すると，一重項酸 素やスーパーオキシドが生成すると報告されてい る9-13). 今回我々は，精油のスーパーオキシドに対する 影響について検討を行らために，リボフラビンを含む反 応溶液中のスーパーオキシド生成に対しティートリーオ イル等各種精油の抗酸化能について, ESR（electron spin resonance: 電子スピン共鳴）装置を用いて検討を行った.

受理日：2009年 5 月 13 日

* 干537-0022 大阪市東成区中本 4-1-8 森ノ宮医療学園専門学校教務部 Tel: 06-6976-6889 Fax: 06-6973-3133 E-mail: hiroko@morinomiya.ac.jp 
材料と方法

\section{1. 材料}

抗炎症作用があると言われている精油の中で，特に使 用頻度の高い，ラベンダースーパーオイル (Lavandula burnatii Super), グレープフルーツオイル (Citrus paradisi), ペパーミントオイル (Mentha piperita), ティートリーオイ ル (Melaleuca alternifolia), ウインターグリーンオイル (Gaultheria procumbens) の 5 種類 (PRANAROM 社, フラ ンス）の精油を使用した.

反応水溶液への溶解性を上げるために，精油を DMSO （dimethyl sulfoxide，和光純薬工業株式会社，大阪府）に 希釈し使用した，光増感剂としてリボフラビン（和光純 薬株式会社, 大阪府），スピントラップ剂として DMPO (5,5-dimethyl-1-pyrroline- $N$-oxide, 東京化成工業株式会社, 東京都）を使用した．反応に抢ける過酸化水素の関与を 調べるためにカタラーゼ (Sigma-Aldrich社, St Louis, Mo., USA) をスーパーオキシドの関与を調べるためにSOD (superoxide dismutase: Sigma-Aldrich 社, St Louis, Mo., USA)を使用した.

\section{2. 方法}

標準反応溶液として, $15 \mu \mathrm{M}$ リボフラビン, $0.10 \mathrm{M}$ DMPO, $23 \mathrm{mM}$ リン酸緩衝液 $(\mathrm{pH} 7.4), 6.3 \%$ (v/v) DMSO を含を混合溶液を用いた. 高圧水銀光源 REX-250 とバン ドパスフィルター（朝日分光株式会社，東京）を用いて $365 \mathrm{~nm}$ の UVA をこの標準反応溶液に 30 秒間照射した. UVA 照射エネルギーは $0.65 \mathrm{~J} / \mathrm{cm}^{2}$ であった.リボフラビ ン標準反応溶液に，濃度 $0.0015 \%(\mathrm{v} / \mathrm{v})$ から $0.13 \%(\mathrm{v} / \mathrm{v})$ のラベンダースーパーオイル, グレープフルーッオイル, ペパーミントオイル，ティートリーオイル，ウインター グリーンオイルをそれぞれ加え, 反応溶液の ESR シグナ ルを測定した。さらに，強いスーパーオキシド生成阻害 活性を認めたティートリーオイルとウインターグリーン オイル中の主成分である $\alpha$-テルピネン， $\gamma$-テルピネン， テルピネン-4-オール打よびサリチル酸メチルをそれぞ れ反応液へ添加して，ESR シグナルを測定した．ESR 測 定には JES-FR 30 Free Radical Monitor（日本電子社，東京 都）を使用した。

\section{結 果}

1. リボフラビン標準反応溶液中のラジカル生成に対す る SOD，カタラーゼおよびェタノール添加の影響 リボフラビン標準反応溶液に, $365 \mathrm{~nm}$ の UVA 照射を 30 秒間行うと $\mathrm{DMPO} / \mathrm{OH}$ ラジカルアダクトの ESR スペ
クトルが検出された（図 1-A）。本標準反応溶液に SOD $(0.93 \mathrm{U} / \mathrm{ml}, 9.3 \mathrm{U} / \mathrm{ml}, 93 \mathrm{U} / \mathrm{ml})$ を添加すると, ESR ピーク 高は濃度依存的に増加した（標準反応溶液に対し，130 \%，180\%，200\%）（図2）。一方，カタラーゼを $28 \mathrm{U} / \mu \mathrm{l}$ 添加しても $\mathrm{DMPO} / \mathrm{OH}$ ラジカルアダクトの生成は減少 しなかった［リボフラビン標準反応溶液に対し $93 \pm 1 \%$ $(\mathrm{n}=3)]$ (表 1). 次に, ヒドロキシラジカルスカベンジャー であるエタノールを $10 \%(\mathrm{v} / \mathrm{v})$ 添加しても, $\mathrm{DMPO} / \mathrm{OH} ラ$ ジカルアダクトのピーク高は核とんど影響を受けなかっ

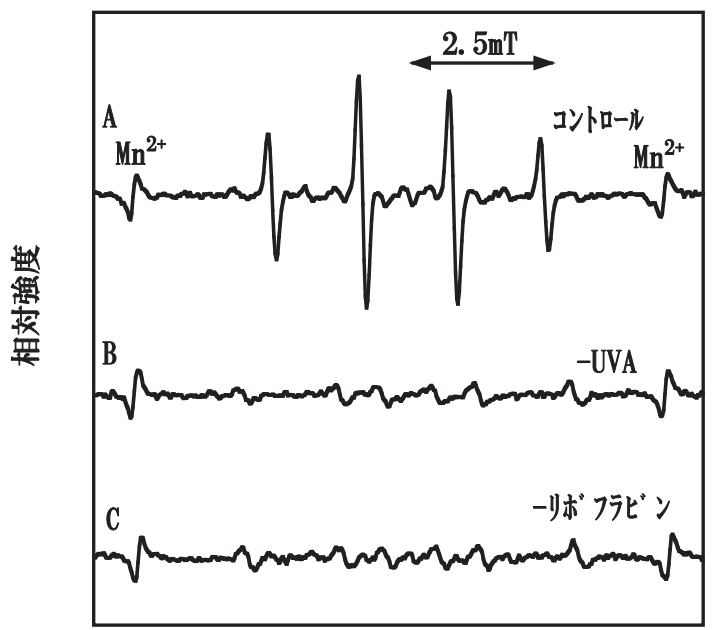

図 1 リボフラビン (Riboflavin) 標準反応溶液に UVA を照射し た時の ESR スペクトル

反応抢よび測定条件は本文に記載したと打りである. A ; リボフ ラビン標準反応溶液に UVAを照射，B；UVA 照射なし，C；リボ フラビンなし

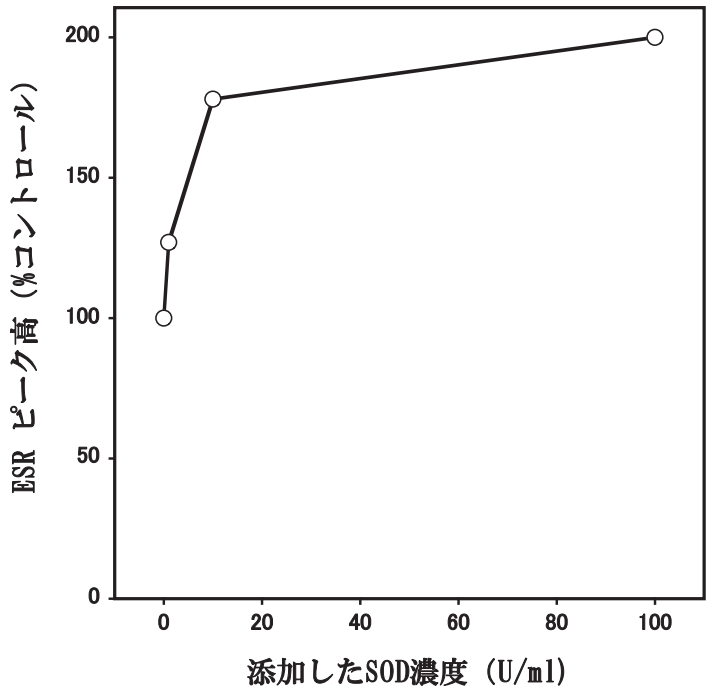

図 $2 \mathrm{DMPO} / \mathrm{OH}$ ESR ピーク高に対する種々の濃度の SOD 添 加の影響

反応および測定条件は本文に記載したとおりである。（各值は単 一測定值) 
た [リボフラビン標準反応溶液に対して $85 \pm 1 \%(\mathrm{n}=3)]$ (表 1).

2. リボフラビン標準反応溶液中のラジカル生成に対す るティートリーオイルの影響

リボフラビン標準反応溶液にティートリーオイルを $0.031 \%(\mathrm{v} / \mathrm{v})$ 添加した結果, ESR ピーク高は 44\% に減少 した（図 3-B).

3. リボフラボン標準反応溶液中のラジカル生成に対す る各種精油の影響

リボフラビン標準反応溶液に, 種々の濃度のラベン ダースーパーオイル, グレープフルーツオイル, ペパーミ ントオイル，ティートリーオイル，ウインターグリーン オイルを加え, ESR シグナルを測定するとそのピーク高 は濃度依存的に減少した（図 4)。その減少率は特に ティートリーオイルやウインターグリーンオイルで大き かった（図 4).

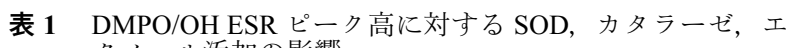
タノール添加の影響

\begin{tabular}{cc}
\hline \multicolumn{1}{c}{ 添加物質 } & コントロール $\%$ \\
\hline $\operatorname{SOD}(9.3 \mathrm{U} / \mathrm{ml})$ & 180 \\
カタラーゼ $(28 \mathrm{U} / \mu \mathrm{l})$ & $93 \pm 1^{\mathrm{a}}$ \\
エタノール $(10 \% \mathrm{v} / \mathrm{v})$ & $85 \pm 1^{\mathrm{a}}$ \\
\hline
\end{tabular}

$\mathrm{a}$ 数值は繰り返し 3 回の平均土標準偏差

反応及び測定条件は本文に記載したと拈りである。

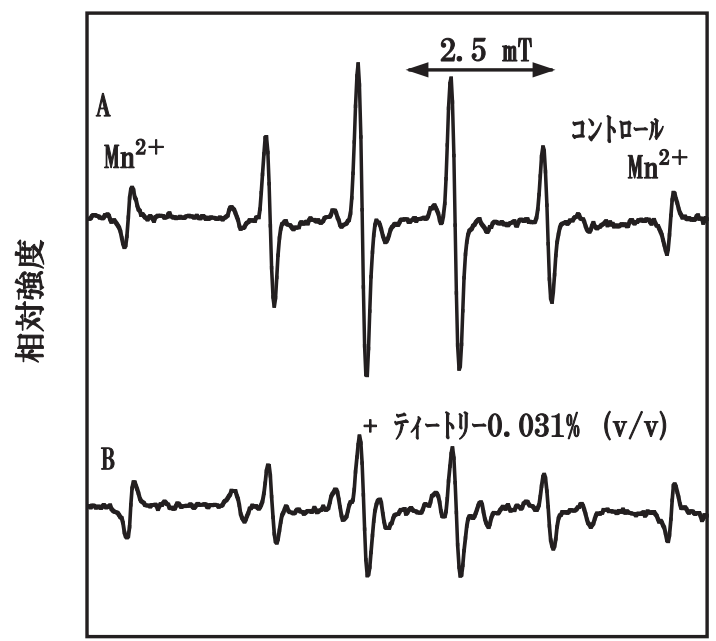

図 3 リボフラビン標準反応溶液に UVA 照射により観測され る ESR シグナルに対するティートリーオイル添加の影 響

反応および測定条件は本文に記載したとおりである。A；リボフ ラビン標準反応溶液に UVA 照射, B; $0.031 \%$ (v/v) ティートリー オイルを添加したリボフラビン標準反応溶液に UVA 照射.
4. ティートリーオイルおよびウインターグリーンオイ ルの主成分のラジカル生成に対する効果

ティートリーオイルには 25 種類の成分が含まれてい る(表2)。これらの成分のらち, 特に含有量が多い $\alpha$-テ ルピネン $(9.57 \%), \gamma$-テルピネン $(21.76 \%)$ ，テルピネ ン-4-オール (39.89\%) について，スーパーオキシド生成 に対するそれぞれの成分の効果を調べた. 各成分を 0.031 \% (v/v) 添加すると，テルピネン-4-オールで ESR のピー ク高が $110 \pm 11 \%(\mathrm{n}=3)$ に, $\gamma$-テルピネンで $49 \pm 5 \%(\mathrm{n}=3)$ に, $\alpha$-テルピネンで $28 \pm 12 \%(\mathrm{n}=3)$ に変化し, $\gamma$-テルピネ ンと $\alpha$-テルピネンに強い抗酸化能を認めた（図 5).

また，ウインターグリーンオイル中に $99.85 \%$ 含まれる

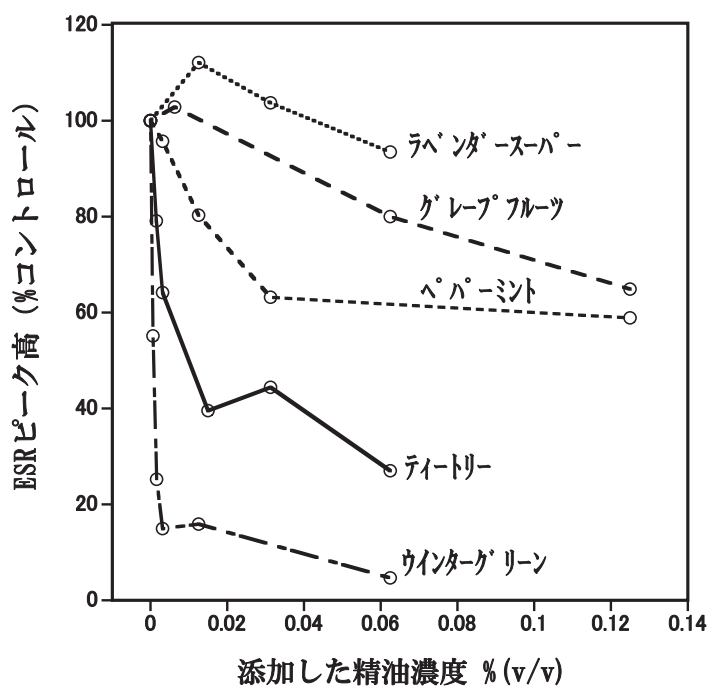

図 4 リボフラビン標準反応溶液に対する各種精油の添加の影 響

反応および測定条件は本文に記載したとおりである，標準反応 溶液の ESR ピーク強度を $100 \%$ と, 種々の濃度の各種精油の 添加による ESR ピーク強度の影響を相対的に表している.（各 值は単一測定值)

表 2 ティートリーオイル (Melaleuca alternifolia)の各成分の含 量 $(\%)$

\begin{tabular}{|c|c|c|c|}
\hline$\alpha$-ツヨネン & 1.04 & テルピネン-4-オール & 39.89 \\
\hline$\alpha$-ピネン & 2.75 & $\alpha$-テルピネオール & 2.90 \\
\hline サビネン & 0.11 & $\alpha$-コパエン & 0.08 \\
\hline$\beta$-ピネン & 0.78 & $\alpha$-グルジュネン & 0.26 \\
\hline ミルセン & 0.97 & $\beta$-カリフォレン & 0.39 \\
\hline$\alpha$-フェランドラン & 0.37 & $\alpha$-ガイエン & 0.91 \\
\hline a-テルピネン & 9.57 & $\beta$-セリネン & 0.08 \\
\hline パラシメン & 2.52 & $\alpha$-セリネン & 0.20 \\
\hline リモネン & 0.69 & $\alpha$-ミュューレン & 0.45 \\
\hline$\beta$-フェランドラン & 0.80 & ビシクロゲルマクレン & 0.72 \\
\hline$\gamma$-テルピネン & 21.76 & カジネン & 0.88 \\
\hline テルピノレン & 3.35 & 1,8-シネオール & 5.65 \\
\hline ビリディフロロール & 0.12 & & \\
\hline
\end{tabular}




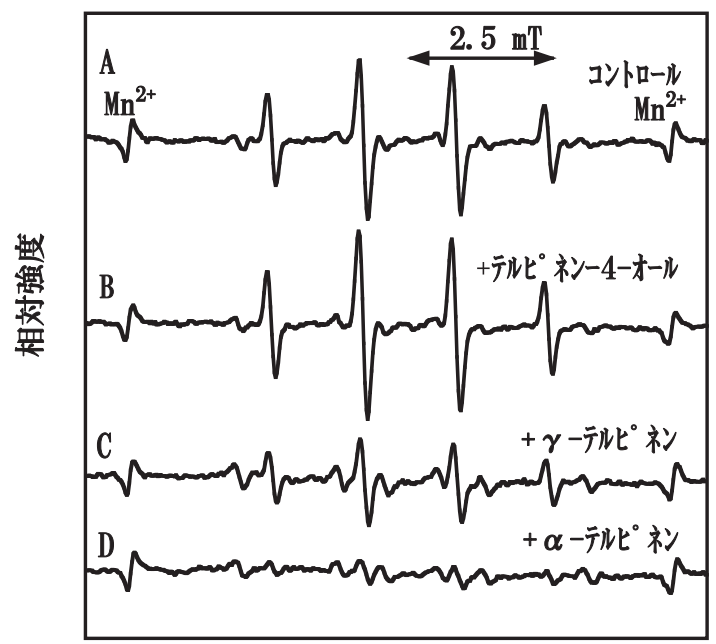

図 5 ティートリーオイルの主成分のスーパーオキシド生成に 対する影響

反応及び測定条件は本文に記載したと扣りである. A ；リボフラ ビン標準反応溶液, $\mathrm{B} ; 0.031 \%(\mathrm{v} / \mathrm{v})$ テルピネン-4-オール添加, $\mathrm{C} ; 0.031 \%(\mathrm{v} / \mathrm{v}) \gamma$-テルピネン添加, D; 0.031\% (v/v) $\alpha$-テルピネン 添加.

サリチル酸メチルを $0.031 \%(\mathrm{v} / \mathrm{v})$ 添加すると, ESR の ピーク高が $12 \pm 1 \%(n=3)$ に変化し, 強い抗酸化能を認め た.

\section{考 察}

リボフラビン光増感反応に拈いて, Krishna らは一重項 酸素扎よびスーパーオキシドが生成すること, その量子 收率がそれぞれ 0.49 扎よび 0.009 であることを報告して いる ${ }^{12)}$. このことより本反応溶液中に一重項酸素が生成 している可能性がある.

一方, 一重項酸素と DMPO との反応により $\mathrm{DMPO} / \mathrm{OH}$ が生成することが明らかにされて打り，一重項酸素の生 成をヒドロキシラジカルの生成と誤解しないように注意 しなければならないと指摘されている14-18). しかし，本 標準反応溶液に SOD を添加すると, ESR ピーク高は濃 度依存的に増加した（図 2)。このことより，本実験にお いて観測されている DMPO/OH は一重項酸素と DMPO の反応により生成されたものではないと考えられる.

一般にヒドロキシラジカルは, 過酸化水素と $\mathrm{Fe}^{2+}$ との 反応（フェントン反応）により生成する.

$$
\mathrm{H}_{2} \mathrm{O}_{2}+\mathrm{Fe}^{2+} \rightarrow \cdot \mathrm{OH}+\mathrm{OH}^{-}+\mathrm{Fe}^{3+}
$$

ところが今回の実験では, 過酸化水素を分解するカタ ラーゼを添加しても $\mathrm{DMPO} / \mathrm{OH}$ ラジカルアダクトの生 成は減少しなかった（表 1)。このことから，ここで検出 された $\mathrm{DMPO} / \mathrm{OH}$ ラジカルアダクトはフェントン反応

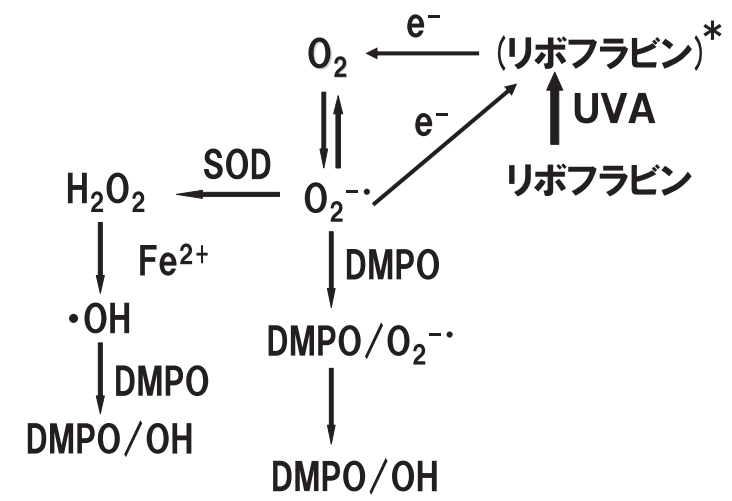

図 6 リボフラビン光増感反応に打ける $\mathrm{DMPO} / \mathrm{OH}$ ラジカルア ダクトの生成機構

によって生じたヒドロキシラジカルをDMPO が直接捕 捉したbのでないことが分かった. さらにヒドロキシラ ジカルスカベンジャーであるエタノールを添加しても, $\mathrm{DMPO} / \mathrm{OH}$ ラジカルアダクトのピーク強度はほとんど影 響を受けなかった（表 1)。このことからも，ヒドロキシ ラジカルをDMPO が直接捕捉したものでもないことが 分かった。

以上のことから DMPO はスーパーオキシドを捕捉し た後, $\mathrm{DMPO} / \mathrm{O}_{2}^{-*}$ ラジカルアダクトが $\mathrm{DMPO} / \mathrm{OH}$ ラジカ ルアダクトに変化しものと思われる（図 6）。 Finkelstein 等により $\mathrm{DMPO} / \mathrm{O}_{2}^{-}$が容易に $\mathrm{DMPO} / \mathrm{OH}$ に変換すると 報告されている19). リボフラビンの光増感反応に扣いて スーパーオキシドが生成するとすでに報告されて拉 $\eta^{12,20)}$, 以上の考察はこのことからも支持される．SOD を添加したとき， DMPO/OH ピーク高が増加したのは $\mathrm{SOD}$ が $\mathrm{O}_{2}^{-*}$ を過酸化水素に変化させ, その過酸化水素か らフェントン反応により·OH が生じたためと思われる (図 6).

観測される $\mathrm{DMPO} / \mathrm{OH}$ の $\mathrm{ESR}$ ピーク高は, 捕捉された $\mathrm{DMPO} / \mathrm{O}_{2}^{-}$ラジカルアダクトの量に比例する. すなわち $\mathrm{DMPO} / \mathrm{OH}$ を測定することによって, 反応溶液中に生成 したスーパーオキシド生成を定量できる.

近年, 精油の抗酸化作用が注目されており, 様々な研 究が進められている6-8,21,22). 本研究に拈いてティート リーオイルとウインターグリーンオイルに, 強い抗酸化 作用を認めた（図 4)。 また，それらの精油の主成分であ る $\gamma$-テルピネン, $\alpha$-テルピネン, サリチル酸メチルに強 い抗酸化能を認めた.

この抗酸化作用はスーパーオキシド生成阻害, スー パーオキシド消去, 光増感剤を消光する等を介している ものと考兄られる. 今後, どの阻害機構を介して抗酸化 作用を発揮しているか検討する必要がある.

今回の研究ではリボフラビン光増感反応に打いて生成 
するスーパーオキシドに対する精油の効果を検討した. アロマセラピーと皮膚組織とは深い関連があるので，今 後, 皮膚組織への光照射に伴って生成するラジカルに対 する精油の効果を検討したい.

今回検討した精油のらち少なくともティートリーオイ ルとウインターグリーンオイルに強い抗酸化能が存在す ることが明らかとなった. 精油成分は皮膚や呼吸器を通 して体内へ容易に吸収されるので，生体内で精油の抗酸 化作用が効果的に発揮される可能性がある. 今後, 生体 中での精油の抗酸化作用についても検討を行い, アロマ セラピーの予防医学, 補完代替医療への活用の可能性を 科学的に検証していきたい.

\section{参 考 文 献}

1) 新島 旭. アロマセラピーの生理学基礎. 日本アロマセラ ピー学会誌. 2007; 6: 13-21.

2) 鳥居鎮夫. アロマセラピーの科学. 東京. 朝倉書店. 2004: 55-78.

3) 甲田雅一, 鮫島浩二, 本間請子ら. ティートリーの抗菌作 用. 日本アロマセラピー学会誌. 2005; 4: 22-27.

4) 甲田雅一, 本間請子, 鮫島浩二ら. 腸管系病原菌に対する ティートリー, マヌカ拈よびマヌカ蜂蜜の抗菌力. 日本ア ロマセラピー学会誌. 2004; 3: 38-44.

5) Hammer KA, Carson CF, Riley TV. Antifungal activity of the components of Melaleuca alternifolia (tea tree) oil. J Appl Microbiol 2003; 95: 853-860.

6) 青 暢子, 佐藤和恵, 須藤絹子ら. 精油の抗酸化作用につ いて—一重項酸素消去能の検討. 日本アロマセラピー学会 誌. 2007; 6: 55-61.

7) 青 暢子, 佐藤和恵, 清水 藍ら. 一重項酸素消去活性か らみた精油の安全使用について。 日本アロマセラピー学会 誌. $2008 ; 7: 36-42$.

8) 佐藤和恵. アロマセラピーとフリーラジカル. 日本アロマ セラピー学会誌. 2007; 6: 28-34.

9) Ahmad I, Fasihullah Q, Noor A, et al. Photolysis of riboflavin in aqueous solution: a kinetic study. Int J Pharm 2004; 280: 199_ 208

10) Chacon JN, McLearie J, Sinclair RS. Singlet oxygen yields and radical contributions in the dye-sensitised photo-oxidation in methanol of esters of polyunsatured fatty acids (oleic, linoleic, linolenic and arachidonic). Photochem Photobiol 1988; 47: 647656.

11) Heelis PF. The photophysical and photochemical properties of flavins (isoalloxazines). Chem Soc Rev 1982; 11: 15-39.

12) Krishna CM, Uppuluri $S$, Riesz $P$, et al. A study of the photodynamic efficiencies of some eye lens constituents. Photochem Photobiol 1991; 54: 51-58.

13) Pajares A, Gianotti J, Stettler G, et al. Modelling the natural photodegradation of water contaminants-A kinetic study on the lightinduced aerobic interactions between riboflavin and 4-hydroxypyridine. J Photochem Photobiol A 2001; 139: 199-204.

14) Harbour JR, Issler SL, Hair ML. Singlet oxygen and spin trapping with nitrones. J Am Chem Soc 1980; 102: 7778-7779.

15) Feix JB, Kalyanaraman B. Production of singlet oxygen-derived hydroxyl radical adducts during merocyanine-540-mediated photosensitization: analysis by ESR-spin trapping and HPLC with electrochemical detection. Arch Biochem Biophys 1991; 291: 43-51.

16) Bilski P, Reszka K, Bilska M, et al. Oxidation of the spin trap 5,5-dimethyl-1-pyrroline $\mathrm{N}$-oxide by singlet oxygen in aqueous solution. J Am Chem Soc 1996; 118: 1330-1338.

17) Takeshita K, Olea-Azar CA, Mizuno M, et al. Singlet oxygendependent hydroxyl radical formation during uroporphyrin-mediated photosensitization in the presence of NADPH. Antiox Redox Signal 2000; 2: 355-362.

18) Nishizawa $C$, Takeshita $K$, Ueda J, et al. Hydroxyl radical generation caused by the reaction of singlet oxygen with a spin trap, DMPO, increases significantly in the presence of biological reductants. Free Radic Res 2004; 38: 385-392.

19) Finkelstein E, Rosen GM, Rauckman EJ. Production of hydroxyl radical by decomposition of superoxide spin-trapped adducts. Mol Pharmacol 1982; 21: 262-265.

20) Massad WA, Marioli JM, Garcia NA. Photoproducts and proposed degradation pathway in the riboflavin-sensitised photooxidation of isoproterenol. Phamazie 2006; 61: 1019-1021.

21) Kim HJ, Chen F, Wu C, et al. Evaluation of antioxidant activity of Australian tea tree (Melaleuca alternifolia) oil and its components. J Agric Food Chem 2004; 52: 2849-2854.

22) Brand C, Ferrante A, Prager RH, et al. The water-soluble components of the essential oil of Melaleuca alternifolia (tea tree oil) suppress the production of superoxide by human monocytes, but not neutrophils, activated in vitro. Inflamm Res 2001; 50: 213219. 


\begin{abstract}
Effects of Some Essential Oils on Superoxide Radical Formation in the Reaction Mixture of Riboflavin under UVA Irradiation

\author{
Hiroko MORI $^{1,2}$, Hideo IWAHASHI ${ }^{1}$ \\ ${ }^{1}$ Department of Chemistry, Wakayama Medical University \\ ${ }^{2}$ Morinomiya College of Medical Arts and Sciences
}

Objective: The effects of essential oils on the formation of superoxide radicals during UVA ( $365 \mathrm{~nm})$ irradiation were investigated. Methods: ESR (electron spin resonance) spin-trapping experiments were performed on a reaction mixture containing $15 \mu \mathrm{M}$ riboflavin, 0.10 M DMPO (5,5-dimethyl-l-pyrroline- $N$-oxide), $23 \mathrm{mM}$ phosphate buffer (pH 7.4) and 6.3\% (v/v) DMSO (dimethyl sulfoxide) (standard reaction mixture) during UVA $(365 \mathrm{~nm})$ irradiation.

Results: On addition of various concentrations of tea tree oil (or lavender super oil or grapefruit oil or peppermint oil or wintergreen oil) to the standard reaction mixture, the ESR peak height decreased dose-dependently.

Conclusion: This result shows that antioxidant activities increase as follows: lavender super oil<grapefruit oil<peppermint oil<tea tree oil<wintergreen oil.
\end{abstract}

Key words: Riboflavin, Superoxide radical, Tea tree oil, ESR (electron spin resonance) 